\title{
Compliance Issues with Public Procurement Regulations in Ghana
}

\author{
Godwin Uzoma Chikwere ${ }^{1}$, Simon S. K. Dzandu ${ }^{2} \&$ Mawuko Dza $^{3}$ \\ ${ }^{1}$ Faculty of Business and Management Studies, Koforidua Technical University, Ghana \\ ${ }^{2}$ Quality Assurance Directorate, Koforidua Technical University, Ghana \\ ${ }^{3}$ School of Business, University of Education, Winneba, Ghana \\ Correspondence: Mawuko Dza, School of Business, University of Education, Winneba, Ghana. E-mail: \\ dzama2010@gmail.com
}

Received: February 1, 2019

Accepted: March 22, 2019

Online Published: April 13, 2019

doi:10.5539/ijbm.v14n5p1

URL: https://doi.org/10.5539/ijbm.v14n5p1

\begin{abstract}
This study examines compliance issues with public procurement regulations in Ghana. The simple random sampling technique was used to draw a sample size of 100 practitioners from public institutions in Ghana. The collected data were analysed using descriptive and inferential statistics. The study revealed that although public procurement entities in Ghana have made some strides in improving compliance levels with the public procurement law, majority of public institutions disregard their management systems and contract management processes among others. The study indicates that familiarity $(p$-value $=0.020)$ though inversely related, incompetence $(p$-value $=0.023)$, political interference $(p$-value $=0.000)$ and poor monitoring $(p$-value $=0.010)$ were significant factors in explaining non-compliance with the legal framework of public procurement in Ghana. The research further discovered that officials in charge of public procurement flout the rules and regulations with impunity. To address the issue of non-conformance by public officials, it is imperative for the Public Procurement Authority to desist from embarking on what could best be described as selective justice and apply the law equally on all non-conforming public institutions. The authority must also strengthen its monitoring systems to ensure that offenders are apprehended and adequately sanctioned according to the law.
\end{abstract}

Keywords: procurement, non-compliance, regulations, public entities

\section{Introduction}

Public procurement remains an important component in the economies of countries across the world, accounting for an estimated $9-13 \%$ of emerging economies' gross domestic product (Thai 2008). It is therefore imperative that governments pay particular attention to public procurement in order to create wealth for the growth and development of their economies (Munyera, 2014). In fact, huge sums of tax payers' money get wasted due to inefficient and ineffective procurement structures, poor monitoring systems, non adherence to policies and procedures, non-compliance to regulations as well as the failure of authorities to impose and implement sanctions for violations of procurement rules (Ntayi et al, 2010a). In order to improve the management of public procurement, many countries have come up with procurement reforms. Ghana's public procurement law was promulgated in December, 2003 to among other things harmonize the processes of public procurement in the public service to secure judicious, economic and efficient use of state resources and ensure that public procurement is carried out in a fair, transparent and non-discriminatory manner (Public Procurement Act 663, 2003). Ghana's public procurement law sets out comprehensible rules and procedures for procurement entities to observe. However, since its enactment, the law has witnessed alarming rates of non-compliance. Indeed, a number of research output on the subject matter confirms the incidence of non-compliance to standards and procedures by procurement practitioners, however very few of these studies have focused on the key determinants or factors that embolden practitioners to consistently flout procurement regulations with impunity. This paper examines the root causes of the issue of non-compliance to procurement regulations by public officials in Ghana. The study further investigates whether familiarity (knowledge of the regulations), staff competence, political interference, poor monitoring and instituting strict rules affect non-compliance with procurement regulations in Ghana.

\section{The Level of Compliance with Public Procurement Regulations in Ghana}

The true level of compliance with public procurement regulations in Ghana has not been clearly determined. Public institutions' attitude towards compliance keeps changing. This is evidenced from research findings of 
academics; reports from the regulatory authority as well as other oversight bodies. For instance, Agbesi (2009) undertook a study on the level of compliance of three entities in the Eastern Region of Ghana and discovered a varying degree of compliance among these institutions with an aggregate score of $67 \%$. Kusi et al., (2014) asserts that compliance has become a major challenge in the implementation of procurement regulations among public institutions in Ghana. Jibrin (2014) affirms that various countries both in developed and emerging economies have instituted procurement reforms involving laws and regulations however the major obstacle has been inadequate regulatory framework to assure compliance. Ameyaw et al., (2012) while analyzing procurement processes in 49 Metropolitan, Municipal and District Assemblies (MMDAs) in the Ashanti and Brong Ahafo regions of Ghana established that procurement practitioners continually perpetuated acts of corruption and also failed to comply with procurement regulations.

\section{Causes of Non-Compliance with Procurement Regulations}

Studies have shown that incidentally the level of familiarity or knowledge of procurement regulations is one of the factors that explain why practitioners fail to comply with procurement regulations (Kariuki 2014). For instance, Kariuki (2014) found that procurement entities in Kenya use alternative methods of procurement instead of open tender and attributed it to incompetence and low familiarity with procurement rules and regulations. A further study by Gelderman et al., (2006) affirm that EU member states have compliance and implementation deficit with the EU procurement directives and further suggested that it is important that member states learn to familiarize themselves with EU directives. This finding is an affirmation of earlier studies by De Boer and Telgen (1998). According to Millerson (2003), professionals must possess adequate skills based on theoretical knowledge; a skill requiring training and education; must demonstrate competence by professionally passing a test; maintenance of integrity by adherence to a code of conduct in delivering service provided for the public good. To this end, for one to qualify as a competent procurement professional, there is the need to meet the criteria advocated by Millerson (2003). Lodhia and Burritt, (2004) acknowledge that social and political influences have a significant connection on public sector reforms. Additionally, ethnicity and tribal influences have resulted in bad practices and total corruption within public institutions (Eyaa 2011). This position is reinforced by Biramata (who adduc (2014e that in developing countries one of the major stumbling blocks to the procurement system is political interference with the tender process where ministers intrude and assumes supremacy over tendering processes. According to a World Bank report (2003), inadequate monitoring and supervision results in lack of compliance with procurement rules and regulations. The possibility of monitoring and review is a strong incentive for procurement officials to abide by laid down rules (Hui et al 2011). Oversight and review functions are critical to exercising good procurement fiduciary management (World Bank, 2003). According to the theory of Cognitive Dissonance proposed by Festinger in 1957, instituting strict rules and compelling forces results in dissonance between ones state of mind and behaviours, which eventually leads to compliance. This presupposes that imposing strict rules on workers eventually cause them to comply with regulations.

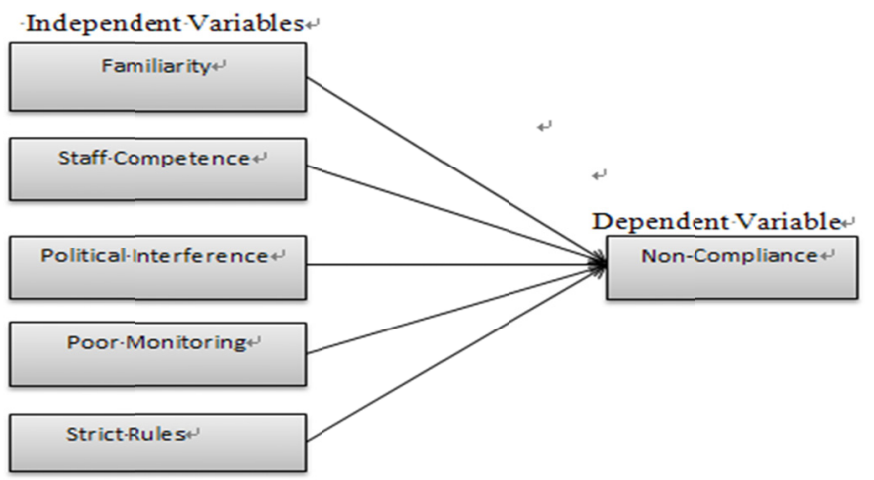

Figure 1. Conceptual Framework on the Causes of Non-compliance

\section{Methodology}

The study was conducted through a descriptive survey research design. Structured questionnaires and the simple random sampling technique were used to draw 100 practitioners from public procurement entities in Ghana. The questionnaire was designed with five independent variables in mind - familiarity, competence, political interference, poor monitoring and strict rules; and non-compliance as the dependent variable. The research also made use of an extract of the compliance assessment tool developed by the World Bank/OECD/DAC (2004) to 
determine the level of compliance with procurement regulations. Respondents were asked to indicate the extent to which they agree or disagree to statements provided on a 1-5 point likert scale, where 1 signifies strongly disagree, 2 signifies disagree, 3 indifferent, 4 agree and 5 strongly agree. A mean distribution skewed towards 1 and 2 was regarded as a negative response, whereas mean distributions skewed towards 4 and 5 and thus beyond 3 was regarded as positive response. Mean distribution centrally positioned towards 3 is regarded as a 0 or no response. The collected data was purely quantitative and was analysed using descriptive and inferential statistics such as means, standard deviations and regression analysis.

The following regression model was generated to show the relationship between the independent variables and the dependent variable.

Where:

$$
Y=\beta_{0}+\beta_{1} X_{1}+\beta_{2} X_{2}+\beta_{3} X_{3}+\beta_{4} \beta_{4}+\beta_{5} X_{5}+\mathrm{e}
$$

$Y$ is non-compliance (response variable)

$\beta_{0}$ is the regression intercept

$\beta_{1}-\beta_{5}$ are the regression coefficients

$X$ is the predictor variables; $X_{1}=$ Low Familiarity, $X_{2}=$ Incompetent Staffs, $X_{3}=$ Political Interference, $X_{4}=$ Strict Rules and $X_{5}=$ Poor Monitoring.

\section{Results and Discussions}

\subsection{Level of Compliance with Procurement Regulations}

Table 1 shows the level of compliance with procurement regulation based on four (4) main areas (Management Systems, Information and Communication, Procurement Process, and Contract Management) of the compliance assessment tool as developed by the Public Procurement Authority.

Table 1. Level of compliance with procurement regulations

\begin{tabular}{llll}
\hline Parameters & N & M & SD \\
\hline Management Systems & & & \\
Putting internal auditors in place and giving them procurement training & 100 & 2.9100 & .88871 \\
Appropriate use of procurement plans and contract documents & 100 & 2.5900 & 1.12002 \\
Carrying out internal procurement auditing & 100 & 2.4600 & 1.14080 \\
Frequent training programs in place & 100 & 2.3100 & 1.26886 \\
Information and Communication & & & \\
Awareness of procurement websites, procurement internal notice boards and newspaper & 100 & 3.7600 & .75371 \\
Use procurement dissemination system & 100 & 3.7300 & .76350 \\
Existence of proficient procurement personnel & 100 & 3.4900 & 1.07774 \\
Having knowledge of and interacting with the market place & 100 & 3.3100 & .92872 \\
Interacting with all procurement stakeholders & 100 & 3.2100 & 1.15728 \\
Procurement Process & & & \\
Notify losers of bids & 100 & 4.2700 & .69420 \\
Notify date, time and venue for bid submission and opening & 100 & 4.1500 & .60927 \\
All bid documents contain same evaluation criteria & 100 & 3.8800 & .87939 \\
Have an adequate defined procurement plan & 100 & 3.8800 & .71464 \\
Advertise tender invitations & 100 & 3.8700 & .96038 \\
Use Standard Tender Document (STD) & 100 & 3.8500 & .78335 \\
Publicize contract awards & 100 & 3.7500 & 1.01876 \\
Post plan on the internet & 100 & 3.7400 & .86012 \\
Notify winners of contract awards & 100 & 3.5300 & .88140 \\
Send information for placement in procurement Bulletin & 100 & 3.3600 & 1.00020 \\
Contract Management & & \\
Preparation of handing over certificates & 100 & 2.8500 & 1.02863 \\
Keep records of item disposed & 100 & 2.7800 & .90543 \\
Comparing and analyzing planned projects against actual & 100 & 2.4900 & 1.01995 \\
Preparation of project monitoring reports & 100 & 2.3300 & .80472 \\
Use of appropriate stock control record system & 100 & 2.2000 & .95346 \\
Organizing of project progress meetings & 100 & 1.9600 & .80302 \\
\hline
\end{tabular}

Note. $\mathrm{N}$ is the sample size of the study; M denotes mean of the distribution; SD denotes Standard Deviation 


\subsection{Management Systems}

All descriptive items captured under management systems in Table 1 show a major disagreement and dissatisfaction by respondents. With a low mean score of 2.31 for whether frequent training programs is in place shows a disagreement by respondents, carrying out internal procurement auditing score 2.46. A mean score of 2.59 and 2.91 shows a disagreement by respondents in terms of appropriate use of procurement plans and contract documents and putting internal auditors in place and giving them procurement training. This confirms the position held by Ferraz and Finan (2007), who outlined among other things, the lack of proper training for procurement staff and other players, absence of internal checks, inappropriate use of procurement plans and poor contract documentations as challenges that confronts procurement reforms. However, this finding contradicts the performance assessment records of the Public Procurement Authority's (PPA) Annual Report, 2009. Though PPA records an improvement in management systems of procurement entities in Ghana from $34.62 \%$ in 2008 to $54.93 \%$ in 2009 , this study shows no improvement in the management systems of entities as far as procurement is concerned.

\subsection{Information and Communication}

From Table 1, Awareness of procurement websites, procurement internal notice boards and newspaper obtained a mean score of 3.76. The use of procurement dissemination system obtained a mean score of 3.73. Existence of proficient procurement personnel obtained a mean score of 3.49. Having knowledge of and interacting with the market place obtained a mean score of 3.31 and interacting with all procurement stakeholders obtained a mean score of 3.21. By and large, it was found that the respondents agreed upon all matters relating to information and communication systems and processes. This indicates that entities adhere to information and communication processes and principles during the procurement process. This position is in line with the PPA's performance assessment record of all public procurement entities in Ghana, which showed an improvement in information and communication systems and processes from 39.82\% in 2008 to 56.03\% in 2009 (PPA Annual Report, 2009).

\subsection{Procurement Process}

Similarly, the mean scores of the items in Table 1 indicate that procurement processes as outlined in the procurement regulations are followed by the public procurement entities (PPEs) in Ghana. Out of the ten items, PPEs are more successful in notifying losers of bids as this item obtained a mean score of 4.27. Notifying date, time and venue for bid submission and opening obtained a mean score of 4.15. All bid documents contain same evaluation criteria and existence of an adequate defined procurement plan secured a mean score of 3.88 and 3.88 respectively. All the other descriptive items had a mean score greater than 3.0 indicating that the respondents are in a total agreement and satisfied with the procurement process of public entities in Ghana. This position is supported by PPA's Nationwide Assessment Report, which shows a massive improvement with the procurement process from $42.65 \%$ in 2008 to $67.73 \%$ in 2009 (PPA Annual Report, 2009). The analysis established that procurement entities in Ghana are complying with the procurement process as enshrined in the procurement Act 633, as amended.

\subsection{Contract Management}

As shown in Table 1, respondents disagreed that public entities prepare handing over certificates (2.85), practitioners keep records of items disposed (2.78). Similarly, with a mean value of 2.49, 2.33, 2.20 and 1.96, it is clear that there has been failure on the part of public procurement entities to compare and analyze planned projects against the actual, prepare project monitoring reports, use appropriate stock control record system and organize project progress meetings respectively. The above indicates that PPE's adhere poorly to contract management processes. This position is in line with the findings of Eyaa (2011) that public institutions and organizations in Ghana have not given contract management the needed attention. This assertion is supported by Kariuki (2013), who posits that most public organizations do no take contract management seriously. In other words the contract management process is fraught with gross inefficiencies. Ironically, this position contradicts the PPA's Performance Assessment Report, which shows an improvement in contract management from 30.66\% in 2008 to $53.98 \%$ in 2009 .

In summary, the data has revealed that generally PPEs adhere to information and communication processes as well as procurement processes. However, with the issue of management systems and contract management processes not much has been done in that regard.

\subsection{Causes of Non-Compliance with Public Procurement Regulations}

Regression analysis was used to determine the relationship between familiarity, staff competence, political interference, poor monitoring, strict rules (independent variables) and non-compliance (dependent variable). 
Results obtained have been presented in tables $2-4$.

Table 2. Multiple correlation coefficient model summary

\begin{tabular}{llccc}
\hline Model & R & R Square & Adjusted R Square & Std. Error of the Estimate \\
\hline 1 & $.554^{\mathrm{a}}$ & .306 & .269 & .42813 \\
\hline
\end{tabular}

a. Predictors: (Constant), poor monitoring, low familiarity, political interference, strict rules, incompetent staff. R denotes multiple regression coefficients; R Square denotes coefficient of determination

Table 3. Regression and residual mean and sum of squares ANOVA ${ }^{\mathrm{b}}$ summary

\begin{tabular}{lllllcl}
\hline \multicolumn{1}{l}{ Model } & Sum of Squares & Df & Mean Square & F & Sig. \\
\hline $1 \quad$ Regression & 7.610 & 5 & 1.522 & 8.304 & $.000^{\mathrm{a}}$ \\
& Residual & 17.230 & 94 & .183 & & \\
& Total & $\mathbf{2 4 . 8 4 0}$ & $\mathbf{9 9}$ & & & \\
\hline
\end{tabular}

Df denotes degree of freedom; $\mathrm{F}$ denotes a test of joint statistics; Sig. denotes significance

Table 4. Regression Coefficients ${ }^{\mathrm{a}}$ of low familiarity, incompetent staff, political interference, strict rules and poor monitoring

\begin{tabular}{|c|c|c|c|c|c|}
\hline \multirow[t]{2}{*}{ Model } & \multicolumn{2}{|c|}{ Unstandardized Coefficients } & \multirow{2}{*}{$\begin{array}{l}\text { Standardized } \\
\text { Coefficients } \\
\text { Beta } \\
\end{array}$} & \multirow[t]{2}{*}{$\mathbf{T}$} & \multirow[t]{2}{*}{ Sig. } \\
\hline & B & Std. Error & & & \\
\hline (Constant) & 1.204 & .245 & & 4.911 & .000 \\
\hline Low familiarity & -.110 & .047 & -.213 & -2.367 & .020 \\
\hline Incompetent Staff & .113 & .049 & .208 & 2.303 & .023 \\
\hline Political interference & .197 & .049 & .359 & 4.042 & .000 \\
\hline Strict rules & -.091 & .046 & -.173 & -1.970 & .052 \\
\hline Poor monitoring & .103 & .039 & .227 & 2.628 & .010 \\
\hline
\end{tabular}

a. Dependent Variable: Non-compliance; Correlation is significant at 0.05 level (2-tailed)

\section{Regression Analysis}

The study conducted a multiple regression analysis so as to determine the combined effect of all the independent variables on non-compliance to public procurement regulations by public institutions. Multiple linear regression analysis is a general statistical technique used to model the relationship between a single dependent variable and several independent variables. The main purpose of multiple regressions is to learn more about the relationship between several independent variables and a dependent variable. The F critical at $5 \%$ level of significance was 8.304. Since F calculated is greater than the F critical (value $=8.304$ ), this shows that the overall model was significant. From Table 4 above, the significance value is 0.000 which is less than 0.05 thus the model is statistically significant in predicting how low familiarity, incompetent staff, political interference strict rules and poor monitoring affects non-compliance to public procurement regulations among public institutions in Ghana.

The study conducted a multiple regression analysis to determine the relationship between independent variables and the dependent variable. The multiple linear regression model for this study was:

$$
Y=\beta_{0}+\beta_{1} X_{1}+\beta_{2} X_{2}+\beta_{3} X_{3}+\beta_{4} \beta_{4}+\beta_{5} X_{5}+\mathrm{e}
$$

Where:

$Y$ is non-compliance (response variable)

$\beta_{0}$ is the regression intercept

$\beta_{1}-\beta_{5}$ are the regression coefficients

$X$ is the predictor variables; $X_{1}=$ Low Familiarity, $X_{2}=$ Incompetent Staffs, $X_{3}=$ Political Interference, $X_{4}=$ Strict Rules and $X_{5}=$ Poor Monitoring.

Therefore the fitted multiple linear regression equation for this study is:

$$
Y(\text { Non-compliance })=1.204-0.213 X_{1}+0.208 X_{2}+0.359 X_{3}-0.173 X_{4}+0.227 X_{5}+\mathrm{e}
$$


From the regression equation established, taking all the factors (Low Familiarity, bid invitation, Incompetent Staffs, Political Interference, Strict Rules and Poor Monitoring) constant at zero, non-compliance in public institutions would be 1.204. Further, if all the other variables are kept constant, a unit increase in low familiarity will lead to a 0.213 increase in non-compliance but in a negative direction. Similarly, a unit increase in Incompetent Staffs will lead to a 0.208 increases in Non-compliance; a unit increase in Political Interference will lead to a 0.359 increase in non-compliance, a unit increase in Strict Rules will lead to a 0.173 increase in non-compliance but in a negative direction and a unit increase in Poor Monitoring will lead to a 0.227 increase in non-compliance to public procurement regulations in public institutions in Ghana. These results imply that of the four variables studied; Political interference contributes most to the non-compliance to procurement regulations by public institutions. The rest are poor monitoring, incompetent staffs, low familiarity, and strict rules in that order follow this. At $5 \%$ level of significance and $95 \%$ level of confidence, low familiarity is negatively related to the non-compliance. This is shown by a negative coefficient (-.213). However, low familiarity is statistically significant as indicated by a P-value of 0.020 , which is statistically significant at $5 \%$. De Boer and Telgen (2008) in a study reported that many public institutions are not conversant with the legal obligations in public procurement and this one of the causes of non-compliance with the law. Winiman (2014) posits that there exist a relationship between familiarity with the procurement rules and its compliance that leads to a positive impact on public procurement in particular and the economy of Ghana in general. The study also found that there is a positive relationship between non-compliance and incompetent staff. Incompetent employees have a statistically significant coefficient as indicated by a P-value of 0.023 , which is statistically significant at $5 \%$. Consistent with this finding is the study of Tukamuhabwa (2012) that indicated that non-compliance is partly due to the significant number of members of the implementation committee in the public sector who are not appropriately competent to handle the compliance process. Political interference on the other hand is positively related to non-compliance and has the most statistically significant coefficient and is indicated by a P-value of 0.00 . Raymond (2004) opined that ministers and political parties receive clandestine payments in government procurement, which ultimately interferes with the procurement process and constrains compliance. This position is further supported by CPAR (2003) who was of the view that political interference with the procurement process is a big challenge to the implementation process and public procurement reforms. Several authors have revealed that contracts are awarded to contractors with political affiliations and this negatively affects value for money in the procurement process (Ameyaw, et al., 2012).

Strict rule is negatively related to non-compliance. A negative sign of the coefficient represents this. The coefficient is statistically insignificant as indicated by P-value of 0.052 . This finding counters the theory of Cognitive Dissonance proposed by Festinger (1957) who was of the opinion that strict rules and compelling forces results in dissonance between ones state of mind and behaviours, which eventually lead to compliance. Again, the researched showed that there is a positive relationship between non-compliance and poor monitoring. Poor monitoring has a statistically significant coefficient as indicated by a P-value of 0.010 , which is statistically significant at $5 \%$. This finding is consistent with Thai (2005) who was of the view that regular checks on procurement entities are necessary to ensure compliance of procurement officials. Osei-Tutu et al (2011) also mentioned that if regular monitoring mechanisms and evaluation of procurement activities are put in place, procurement entities would comply with laid down rules and regulations governing procurement operations. This implies that if entity's procurement activities are not properly monitored, non-compliance will continue to be the order of the day. This indicates a positive correlation between non-compliance and poor monitoring. Hence, this finding conforms to exiting literature. From the fitted regression model, it was noted that the regression had a correlation coefficient (R Square) of about 0.306 and an adjusted R Square of 0.269 . This means that low familiarity, incompetent staffs, political interference, strict rules and poor monitoring accounts for $27 \%$ of the variations in non-compliance to procurement regulations. The other remaining $73 \%$ are factors not considered in this study. Further research should therefore be conducted to investigate the other factors $(73 \%)$ that affect non-compliance with procurement regulations in public institutions. The F-stats of 8.304 at $5 \%$ significance level is significant indicating that the joint contribution of the independent variables was significant in predicting the dependent variable.

\section{Conclusion}

This paper surveyed 100 procurement officers of public procurement entities in Ghana. The paper sets to find out the level of compliance with the procurement law and factors responsible for non-compliance with procurement regulations in Ghana. The study found that on the average, there has been modest improvement in the compliance level of the procurement law. The research revealed that low familiarity and strict rules are negatively related to non-compliance and for that matter does not explain non-compliance. Factors that explain 
non-compliance were found to include; staff competence, political interference and poor monitoring. At $5 \%$ level of significance; low familiarity ( $p$-value $=0.020)$, incompetence $(p$-value $=0.023)$, political interference $(p$-value $=0.000)$ and poor monitoring $(p$-value $=0.010)$ were significant in explaining variations in non-compliance, but accounted for only $27 \%$ of the variation in non-compliance with procurement regulation in public procurement entities in Ghana. It is therefore recommended that further research be undertaken to investigate the other factors $(73 \%)$ in procurement that affects non-compliance purposely to ascertain how these other factors also contribute to non-compliance to public procurement in public institutions. Knowing the root causes of non-compliance will help policy makers direct their policies towards addressing and improving public procurement compliance issues in Ghana.

\section{References}

Agbesi, K. (2009). Compliance Assessment of the Public Procurement Act, 2003 (Act 663): Case Study of Selected Government Institution in the Eastern Region; Unpublished Thesis. Retrieved from http://hdl.handle.net/123456789/268

Ameyaw, C., Mensah, S., \& Osei-Tutu, E. (2012) Public procurement in Ghana: the implementation challenges to the public procurement law 2003 (Act 663). International Journal of Construction supply chain management, 2(2), 55-65.

Biramata, R. A. (2014). Challenges of Compliance to Public Procurement Act No. 7 Of 2011 the Case of Tanzania Ports Authority. Retrieved from http://repository.out.ac.tz/563/1/DISSERTATION_RICHARD_BIRAMATA.pdf

De-Boer, L., \& Telgen, J. (1998) Purchasing Practice in Dutch Municipalities. International Journal of Purchasing and Materials Management, 34(2), 31-36.

Eyaa, S. \& Oluka, P. (2011). Explaining Non- Compliance in Public Procurement in Uganda. International Journal of Business and Social Science, 2(11).

Ferraz, C. \& Finan, F. (2007): Exposing Corrupt Politicians: The Effects of Brazil's Publicly Released Audits on Electoral Outcomes. Discussion Paper, 2836. https://doi.org/10.1162/qjec.2008.123.2.703

Festinger, 1. (1957). A Theory of Cognitive Dissonance. Evanston, Ill: Row Peterson Prayas.

Gelderman, J. C., Ghijsen, W. P. \& Brugman, J. M. (2006). Public procurement and EU Tendering DirectivesExplaining Non-Compliance. International Journal of Public Sector Management, 19(7), 702-714. https://doi.org/10.1108/09513550610704716

Hui, W. S., Othman, R. O., Normah, O., Rahman, R. A. \& Haron, N. H. (2011). Procurement Issues in Malaysia. International Journal of Public Sector Management, 24(6), 567-593. https://doi.org/10.1108/09513551111163666

Jibrin, M. S., Ejura, S. B., \& Nwaorgu. I. A. (2014). The Public Procurement Reforms in Nigeria: Implementation and Compliance Challenges. Journal of Asian Business Strategy, 4(11), 149-162.

Kariuki, T. J. (2014). Factors Affecting Compliance of Public Hospitality Entities to Public Procurement Laws and Regulations in Kenya. International Journal of Business and Commerce, 2(10).

Kusi, L.Y., Aggrey, G. A. B., \& Nyarku, K. (2014). International Journal of Academic Research in Business and Social Sciences, 4.

Lodhia, S. K., \& Burritt, R. L. (2004). Public Sector Accountability Failure in an Emerging Economy: The Case of the National Bank of Fiji. International Journal of Public Sector Management, 17(4), 345-359. https://doi.org/10.1108/09513550410539820

Millerson, G. (2003). The Qualifying Associations. Routledge and Kegan Paul.

Munyera, P. S. (2014). Investigating Causes for Non-Compliance to Public Procurement Legal Framework in Public Institutions Case Study-Tanzania Bureau of Standards. Retrieved from http://scholar.mzumbe.ac.tz/bitstream/handle/11192/824/MSc_PSCM_Pauline\%20Simon\%20Munyera_201 3.pdf

Ntayi, J. M., Byabashaija, S., Eyaa, S., Ngoma, M., \& Muliira, A. (2010a). Social Cohesion, Groupthink and Ethical Behavior of Public Procurement Officers, Journal of Public Procurement, 10(1), 68 -92. https://doi.org/10.1108/JOPP-10-01-2010-B003

Osei-Tutu, E., Sarfo, M., \& Ameyaw C. (2011) The Level of Compliance with the Public Procurement Act 
(Act 663) in Ghana. Retrieved from http://resolver.tudelft.nl/uuid:f6134e5f-f6e4-4f37-b547-90e8d5fdd642

Raymond, W. C. (2004) Accountability and Responsibility in Organizations: The Ethics of Discretion. Public Policy in Administration, 13, 39-48.

Thai, K. V. (2005). Public Procurement Re-Examined. Journal of Public Procurement, 1(1), 9-50. https://doi.org/10.1108/JOPP-01-01-2001-B001

Tukamuhabwa, B. R. (2012). Antecedents and Consequences of Public Procurement Non- Compliance Behavior, Journal of Economics and Behavioral Studies, 4(1), 34-46. Retrieved from http://eprints.lancs.ac.uk/id/eprint/72861

World Bank. (2003). Annex 8-Public Procurement Act. Washington, DC: World Bank. Retrieved from http://documents.worldbank.org/curated/en/617251468771002248/Annex-8- Public-Procurement-Act

\section{Copyrights}

Copyright for this article is retained by the author(s), with first publication rights granted to the journal.

This is an open-access article distributed under the terms and conditions of the Creative Commons Attribution license (http://creativecommons.org/licenses/by/4.0/). 